\title{
EFEKTIVITAS PSIKOTERAPI INTERPERSONAL UNTUK MENURUNKAN DEPRESI PADA REMAJA PUTRI DENGAN ORANGTUA BERCERAI
}

\section{EFFECTIVENESS OF INTERPERSONAL PSYCHOTHERAPY TO REDUCE DEPRESSION SYMPTOMS IN ADOLESCENT GIRL WITH PARENTAL DIVORCE}

\author{
Noviza \\ Fakultas Psikologi dan Ilmu Sosial Budaya Universitas Islam Indonesia Yogyakarta \\ Email:noviza_azz@yahoo.co.id \\ Koentjoro \\ Fakultas Psikologi Universitas Gadjah Mada Yogyakarta
}

\begin{abstract}
This study aims to reduce symptoms of depression in adolescent girls with interpersonal psychotherapy (IPT). Subjects in this study ware adolescent girl with divorced parents, aged 15 to 17 years old, and have symptoms of depression. Measuring devices using the Beck Depression Inventory (BDI-II). This study used an experiment-qualitative method with action research approach. Analysis of the data using a visual inspection by looking at the changes in scores increase or decrease in individual. The results of this study concluded that interpersonal psychotherapy is effective to reduce symptoms of depression in adolescent girls with divorced parents. The results of qualitative analysis showed that subjek felt more happy, be positive, not hopeless, effective communication skills, and be able to resolve their problems in a mature.
\end{abstract}

Keywords: Interpersonal Psychotherapy, Depression, Adolescent

\begin{abstract}
ABSTRAK
Penelitian ini bertujuan untuk menurunkan gejala depresi pada remaja putri dengan orangtua bercerai dengan psikoterapi interpersonal. Subjek dalam penelitian ini adalah remaja putri usia 15 hingga 17 tahun, berasal dari keluarga dengan orangtua yang telah bercerai lama, dan terdiagnosis mengalami depresi. Alat ukur yang digunakan adalah Beck Depression Inventory (BDI-II). Penelitian ini menggunakan metode eksperimental kualitatif dengan pendekatan action research. Analisis data menggunakan visual inspection dengan melihat perbandingan berupa kenaikan atau penurunan skor secara individual. Hasil penelitian dapat disimpulkan bahwa psikoterapi interpersonal terbukti efektif untuk menurunkan gejala depresi remaja putri dengan orangtua bercerai. Hasil analisis kualitatif menunjukkan bahwa subjek merasa lebih bahagia, dapat berpikir positif, tidak putus asa, memiliki kemampuan komunikasi yang efektif, dan mampu menyelesaikan permasalahan secara dewasa.
\end{abstract}

Kata kunci: Psikoterapi interpersonal, Depresi, Remaja Putri 
Perkembangan era globalisasi di Indonesia membawa dampak positif maupun negatif bagi masyarakatnya, termasuk dalam kehidupan sosial. Dampak positif yang bisa dirasakan adalah keterbukaan pola pikir terhadap teknologi yang dapat menunjang kehidupan. Namun, juga banyak dampak negatif yang terjadi. Salah satunya adalah penurunan nilai-nilai normatif dalam masyarakat. Degradasi nilai mencakup nilai agama, nilai sosial, adat istiadat, dan nilai kesakralan sebuah keluarga. Salah satunya dapat dilihat gejalanya saat ini, yaitu angka perceraian yang terus meningkat, seakan-akan menjadi trend yang menghilangkan kesakralan dan makna dari sebuah pernikahan. Di Daerah Semarang misalnya, pada tahun 2012, perkara perceraian yang masuk ke Pengadilan Agama (PA) Semarang mencapai kasus 2.885 dan mengalami peningkatan pada tahun 2013 sebanyak 3.237 kasus perceraian (http://www.pa-sema rang. go.id/ layanan-publik/statistik-perkara.html). Berdasarkan data Pengadilan Agama Semarang dapat terlihat jelas pening katan angka perceraian setiap tahunnya.

Perceraian tentu akan membawa perubahan dalam kehidupan keluarga, terutama dalam kehidupan anak hasil perkawinan tersebut. Berbagai penelitian menyebutkan bahwa pada umumnya perceraian membawa resiko yang besar pada anak dari sisi psikologis. Oldehinkel, Ormel, Veenstra, De Winter, dan Verhulst (2008) dalam penelitiannya menemukan bahwa dengan bertambah- nya usia anak, perceraian orangtua menjadi sangat terkait dengan gejala depresi. Anak yang memiliki orangtua bercerai akan lebih banyak terkena konflik dan kesedihan dibanding dengan anak yang tumbuh dalam pernikahan stabil.

Wong (2009) menyatakan sekalipun perceraian dapat menghasilkan dampak positif, namun dampak negatifnya lebih besar. Dampak positif perceraian adalah terselesaikannya konflik di dalam keluarga, kemandirian, serta kedewasaan. Akan tetapi, dampak negatif yang ditimbulkan dari perceraian orangtua lebih besar dibandingkan dengan dampak positif. Perceraian orangtua akan membuat anak tidak mampu melepaskan diri dari konflik orangtua, merasa kehilangan keluarga, kekhawatiran akan dirinya sendiri, rasa khawatir pada orangtua dan saudaranya, sedih, malu, menarik diri dari temantemannya, terganggunya konsep seksualitas ketika dewasa.

Pengamatan yang dilakukan peneliti terhadap fenomena yang ada di lapangan serta wawancara yang dilakukan terhadap lima orang remaja tengah kisaran usia 15 hingga 16 tahun yang berasal dari orangtua bercerai mendukung pernyataan di atas. Hasil pengamatan menunjukkan bahwa anak yang orangtuanya bercerai merasakan berbagai afek negatif, seperti perasaan sedih, merasa tidak berguna, gangguan tidur, kekhawatiran akan masa depan, dan adanya niatan untuk bunuh diri. 
Seharusnya masa remaja merupakan suatu masa pertumbuhan dan perkembangan, saat individu berkembang untuk mencapai kematangan seksualnya. Remaja mengalami perkembangan psikologi dan pola identifikasi dari anak-anak menuju dewasa. Fase ini merupakan masa penentuan bagi remaja. Apabila pada tahap ini perkembangan remaja terhambat, maka akan berpengaruh pada perkembangan emosional dan kepribadiannya di fase berikutnya (Alwisol, 2009). Serupa dengan itu, Sarwono (2006) menjelaskan bahwa pada masa remaja individu dihadapkan pada berbagai macam perubahan yang cepat dan permasalahan yang menyertainya yang dapat menjadi stressor. Oleh karena itu remaja diharapkan mampu mengatasi stressor yang muncul secara lebih mandiri. Apabila terjadi kendala, maka remaja tidak mampu mengatasi stressor sehingga akan muncul kecenderungan munculnya gejala depresi.

Seperti yang dijelaskan oleh Storksen, Røysamb, Moum, dan Tambs (2005) perceraian orangtua dapat membawa efek jangka panjang bagi anak. Terlebih ketika orangtua bercerai saat anak masih kecil, karena dampaknya akan terbawa hingga mereka memasuki usia dewasa. Hal serupa yang dialami oleh kelima subjek, orangtua subjek mengalami perpisahan ketika subjek masih anakanak, sehingga membawa dampak ke fase berikutnya. Masalah yang biasanya terjadi pada remaja awal hingga tengah adalah penarikan diri, kecemasan, depresi, masa- lah sosial, kenakalan, dan perilaku agresif. Secara umum, gejala depresi pada anak dengan orangtua bercerai akan mengalami kenaikan pada usia remaja, khususnya remaja putri. Oldehinkel dkk (2008) yang meneliti tentang perbedaan depresi remaja laki-laki dan perempuan dengan orangtua bercerai menjelaskan bahwa dengan bertambahnya usia anak, perceraian orang-tua menjadi sangat terkait dengan gejala depresi pada anak, khusunya bagi anak perempuan. Hasil penelitiannya menyebutkan bahwa anak perempuan dengan orangtua bercerai beresiko tinggi mengembangkan gejala depresi selama masa remaja. Hal ini sangat terkait dengan perubahan sosial budaya, hormonal, serta kebutuhan afiliasi anak perempuan lebih besar dibandingkan dengan anak laki-laki.

Oldehinkel dkk (2008) menambahkan anak dengan orangtua bercerai umumnya akan terkena lebih banyak kesedihan dan konflik dibandingkan dengan anak yang tumbuh di dalam keluarga yang stabil. Padahal seharusnya remaja harus dapat melewati masa peralihan dari kanak-kanak menuju dewasa dengan baik. Adanya permasalahan dalam hidup remaja tentu memengaruhi remaja dalam mencapai tugas-tugas perkembangannya, di mana pada masa ini remaja harus mampu menerima keadaannya, mampu membina hubungan baik dengan lawan jenis, mandiri secara emosional, memahami nilai-nilai orangtua dan orang dewasa, serta mempersiapkan diri untuk kehidupan berkeluarga kelak (Hurlock, 2010). 
Auerbach dan Ho (2012) dalam penelitiannya tentang depresi pada remaja menyatakan bahwa remaja sangat rentan untuk mengembangkan depresi dan memiliki dampak yang cukup panjang, yang akan memengaruhi psikososial ketika dewasa. Terlebih remaja merupakan masa "storm and stress" yang dipenuhi oleh berbagai perubahan dan terkadang muncul permasalahan sulit dalam hidupnya untuk menuju ke masa dewasa (Santrock, 2003). Oleh sebab itu dibutuhkan penanganan berupa intervensi kepada subjek. Tujuannya adalah agar gejala depresi yang dialami saat ini dapat diatasi dengan baik.

Berbagai penelitian dan intervensi telah banyak dilakukan untuk mengatasi depresi yang dialami remaja. Akan tetapi, fenomena permasalahan remaja semakin banyak dan mendapat perhatian untuk diteliti lebih lanjut. Dalam penelitiannya Auerbach dan Ho (2012) menjelaskan bahwa sampai saat ini Cognitive Behavior Therapy (CBT) adalah intervensi nonpharmacologic paling banyak digunakan untuk mengatasi depresi pada remaja. Akan tetapi, Auerbach dan Ho mencoba memadukan terapi kognitif dan Psikoterapi Interpersonal. Hasilnya menunjukkan ada perubahan yang signifikan, yaitu penurunan tingkat depresi pada remaja usia 12 hingga 18 tahun dari waktu ke waktu. Auerbach dan Ho (2012) menjelaskan CBT dalam kasus remaja memiliki kekurangan, yaitu keterbatasan dalam menangani kasus yang terkait dengan interpersonal. Dalam penelitiannya dije- laskan bahwa erat kaitannya dan ada saling timbal balik antara hubungan interpersonal remaja dan gejala stres atau depresi yang muncul. Oleh sebab itu CBT saja tidak cukup, diperlukan terapi yang secara khusus mengatasi permasalahan interpersonal pada remaja.

Salah satu penelitian yang mendapat dukungan dari American Academy of Pediatrics Mental Health dan telah terbukti efektif untuk kasus depresi pada remaja yaitu Psikoterapi Interpersonal (PI). Terapi ini pernah diteliti oleh Klomek, Zalsman, dan Mufson (2007). Interpersonal Psychotherapy for Adolescent (IPTA) merupakan intervensi berupa psikoterapi baru yang dikembangkan dan telah terbukti efektif untuk menangani permasalahan klinis, termasuk dalam kasus depresi yang dialami oleh remaja. Psikoterapi interpersonal untuk remaja merupakan terapi yang dimodifikasi dari psikoterapi interpersonal dewasa. Psikoterapi interpersonal untuk remaja berfokus pada permasalahan remaja antara usia 12 hingga 18 tahun, dengan kategori ringan hingga sedang. Psikoterapi interpersonal berupaya untuk mengatasi permasalahan interpersonal remaja dengan mengembangkan keterampilan komunikasi dan dalam memecahkan persoalan. PI membantu remaja memahami dampak dari peristiwa interpersonal dan kaitannya dengan perubahan suasana hati yang dirasakan. Psikoterapi interpersonal cocok untuk permasalahan yang terkait dengan interpersonal seperti perpisahan orangtua, pola asuh otoriter dari orangtua, kematian 
keluarga atau teman, tekanan teman sebaya, dan keluarga dengan orangtua tunggal.

Berdasarkan penelitian-penelitian yang sudah dilakukan sebelumnya, peneliti memilih Psikoterapi Interpersonal sebagai alternatif untuk mengatasi depresi yang dialami subjek. PI bekerja dengan memfokuskan interpersonal subjek, sifatsifat dan kelemahannya, serta meningkatkan hubungan tersebut. Intervensi ini dipilih karena apabila seseorang memiliki hubungan yang kuat, sehat, dan penuh penghargaan dengan orang lain, kecil kemungkinan untuk menjadi depresi atau mempertahankan kondisi depresinya, sehingga individu tersebut akan merasa bahagia. Terapi ini sangat cocok dalam kasus subjek yang menginjak usia remaja, karena psikoterapi interpersonal ada yang telah memodifikasi untuk kasus remaja dan hasilnya adalah signifikan untuk menurunkan depresi pada remaja (Klomek, Zalsman, \& Mufson, 2007).

Berdasarkan uraian di atas, maka peneliti ingin menguji apakah Psikoterapi Interpersonal efektif untuk mengurangi depresi yang dialami oleh remaja putri dengan orangtua bercerai? Hipotesis yang diajukan adalah psikoterapi interpersonal efektif untuk mengurangi depresi pada remaja yang orangtuanya bercerai.

\section{METODE PENELITIAN}

\section{Rancangan Penelitian}

Penelitian ini merupakan penelitian dengan menggunakan metode eksperi- mantal kualitatif dengan pendekatan action research. Rancangan penelitian ini adalah rancangan eksperimen dalam kelompok yang sama (within subjects design), yaitu remaja putri dengan orangtua bercerai. Desain satu kelompok dengan pengukuran prates, pemberian perlakuan, pascates kemudian follow-up. Langkah-langkah yang dilakukan peneliti dalam melakukan pengumpulan data ini adalah (1) wawancara, (2) observasi, dan (3) skala.

\section{Subjek Penelitian}

Subjek dalam penelitian ini ada lima orang remaja putri usia antara 15 tahun sampai 17 tahun. Subjek berasal dari keluarga dengan orangtua bercerai lama dan telah memiliki keluarga baru.

\section{Metode Pengumpulan Data}

Teknik pengumpulan data dilakukan adalah dengan wawancara, observasi, dan skala. Skala depresi yang digunakan adalah Beck Depression Inventory (BDI-II) yang bertujuan untuk mengukur tingkat depresi remaja. Skala BDI yang digunakan sudah diadaptasi di Indonesia.

\section{Intervensi}

Terapi yang diberikan pada penelitian ini adalah Psikoterapi Interpersonal (PI). Pelatihan dilakukan sebanyak empat kali pertemuan, yaitu pada tanggal 22 Mei, 23 Mei, 28 Mei, dan 29 Mei 2014. Fasilitator dalam Psikoterapi Interpersonal ini adalah seorang Psikolog Klinis dibantu oleh dua orang observer 
yang mengobservasi peserta, terapis, serta proses pelaksanaan terapi tersebut.

\section{Metode Analisis Data}

Analisis data penelitian dilakukan dengan visual inspection. Gejala depresi subjek dibandingkan antara hasil pengukuran sebelum perlakuan (prates), setelah perlakuan (pascates), dan follow-up skala BDI-II. Perbandingan secara individual tampak pada kenaikan atau penurunan yang disajikan melalui tabel atau grafik.

\section{HASIL PENELITIAN}

Hasil analisis data tersaji dalam data kualitatif dan visual inspection. Secara kualitatif, dapat disimpulkan bahwa psikoterapi interpersonal membawa pengaruh positif bagi subjek. Subjek juga menyatakan manfaat lainnya dari psikoterapi interpersonal yang dapat disimpulkan sebagai berikut: (1) subjek merasa lebih lega karena bisa mengungkapkan perasaan dan emosinya, (2) subjek menjadi mengerti permasalahan apa yang terjadi pada dirinya dan apa saja dampaknya, (3) subjek jadi lebih memahami dan menerima kondisi yang telah terjadi, (4) subjek menjadi lebih sabar dan mampu mengontrol emosi negatif akibat konflik yang dialaminya, (5) subjek memahami dan dapat mempraktikkan komunikasi efektif, sehingga memperbaiki konflik interpersonal yang secara tidak langsung berkaitan dengan gejala depresi, (6) subjek mengetahui kekurangan dalam diri dan mengerti apa yang harus diperbaiki dari dirinya sehingga memudahkan subjek dalam melakukan perubahan perilaku yang lebih positif, (7) menjadi lebih semangat ke depannya dalam menghadapi kehidupan.

Analisis kuantitatif dilakukan dengan visual inspection berdasarkan hasil analisis deskriptif mean empirik pada skala BDI-II subjek. Dari analisis dapat disimpulkan bahwa keenam subjek di atas mengalami penurunan yang signifikan. Berikut hasil dari masingmasing subjek:

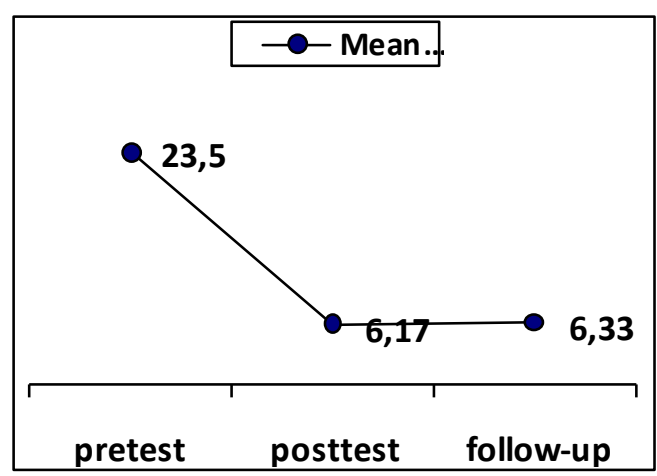

Grafik1. Mean Empirik Subjek

\section{PEMBAHASAN}

Penelitian tentang depresi beberapa dekade terakhir ini lebih banyak menarik minat peneliti, khususnya pada sampel dengan usia muda. Hal ini dikarenakan remaja berada pada masa storm and stress yang dipenuhi oleh berbagai perubahan dan terkadang muncul permasalahan sulit dalam hidupnya untuk menuju ke masa dewasa (Santrock, 2003). Gejala depresi pada remaja biasanya berkaitan erat dengan konflik interper- 
sonal (Auerbach \& Ho, 2012) sebagaimana penelitian ini, yang mengangkat kasus gejala depresi pada remaja putri dengan orangtua bercerai. Penelitian ini bertujuan untuk memberikan solusi dengan psikoterapi interpersonal dalam menurunkan gejala depresi pada remaja putri. Berdasarkan hasil analisis data yang dilakukan, psikoterapi interpersonal memiliki pengaruh dan terbukti efektif untuk menurunkan gejala depresi remaja. Hasil yang diperoleh dari deskripsi data mean empirik subjek mengalami penurunan sebelum dan setelah intervensi diberikan. Mean empirik sebelum intervensi 23.5 dan setelah intervensi menurun menjadi 6.17. Hasil analisis deskripsi data kemudian peneliti jabarkan ke dalam grafik perubahan masing-masing subjek. Hasilnya, subjek mengalami penurunan gejala depresi berdasarkan hasil tes Beck Depression Inventory (BDI-II).

Analisis kualitatif yang peneliti lakukan kepada masing-masing subjek juga menunjukkan hasil yang cukup positif. Setiap subjek merasakan perubahan setelah mengikuti psikoterapi interpersonal, baik dari segi emosional maupun perilakunya. Berdasarkan hasil analisis kuantitatif dan kualitatif, maka peneliti menyimpulkan bahwa psikoterapi interpersonal terbukti efektif untuk menurunkan gejala depresi remaja putri dengan orangtua bercerai. Hal tersebut sesuai dengan berbagai penelitian yang menyebutkan bahwa psikoterapi interpersonal merupakan terapi yang efektf untuk menangani kasus klinis, termasuk di dalamnya kasus depresi pada remaja (Klomek, Zalsman, \& Mufson, 2007).

Storksen dkk (2005) menjelaskan bahwa perceraian orangtua dapat membawa efek jangka panjang bagi anak, terlebih saat orangtua bercerai anak masih kecil. Dampaknya akan terbawa hingga mereka memasuki usia remaja hingga dewasa. Setelah bercerai tentu akan timbul permasalahan baru di dalam keluarga. Pada kasus subjek, permasalahan yang ditimbukan adalah konflik interpersonal yang memunculkan emosi negatif pada diri subjek. Storksen dkk (2005) menambahkan permasalahan yang biasanya terjadi pada remaja awal sampai tengah salah satunya adalah gejala depresi.

Secara umum, gejala depresi pada anak dengan orangtua bercerai akan mengalami kenaikan pada usia remaja, khususnya remaja putri seperti subjek dalam penelitian ini. Salah satu faktor yang dikontrol dalam penelitian ini adalah jenis kelamin. Peneliti hanya menggunakan remaja putri. Menurut Ingersall (McLean, 2003), terdapat perbedaan yang sangat signifikan antara remaja laki-laki dengan remaja putri dalam hal mengalami depresi. Pada masa ini prevalensi remaja putri mengalami depresi sampai dua kali lipat dibanding dengan remaja laki-laki. Adanya perubahan hormonal yang menyertai pubertas mengakibatkan meningkatnya resiko remaja putri mengalami depresi. Remaja laki-laki cenderung mengalihkan diri dari perasaan depresi pada masa ini, sedangkan remaja putri 
lebih sensitif dan merenungkan apa yang terjadi sehingga memperkuat resiko untuk menjadi depresi.

Auerbach dan Ho (2012) menjelaskan bahwa konflik keluarga merupakan pemicu besar penyebab stres interpersonal. Stres tersebut memberikan kontribusi ke tingkat yang lebih tinggi, yaitu gejala depresi. Berdasarkan keterangan tersebut dapat disimpulkan bahwa ada keterkaitan yang antara konflik interpersonal dan gejala depresi. Dengan memperbaiki konflik interpersonal gejala depresi subjek akan menurun. Komunikasi yang tidak efektif merupakan alasan utama seseorang mengalami konflik interpersonal (Robertson, Rushton, \& Wurm, 2008). Menurutnya, dalam penelitian psikoterapi interpersonal terapis harus secara khusus memperbaiki komunikasi yang gagal menjadi lebih efektif. Analisis komunikasi yang baik dilakukan adalah dengan pemecahan masalah dengan role-play.

Hasil analisis kualitatif menyimpulkan bahwa secara keseluruhan permasalahan utama yang menyebabkan emosi negatif seperti gejala-gejala depresi adalah komunikasi yang sering gagal atau tidak efektif antar individu, dalam hal ini adalah keluarga. Salah satu contoh ketidakmampuan dalam berkomunikasi dengan baik adalah konflik kerap kali muncul, baik dengan orangtua kandung, saudara kandung, orangtua sambung, dan saudara tiri. Konflik yang sering timbul dan tidak segera diselesaikan mengakibatkan gagalnya komunikasi tersebut, me- munculkan perasaan-perasaan sedih, putus asa, merasa tidak dianggap, hingga terjadi perubahan reaksi fisik yang berakibat pada pola makan dan tidur yang terganggu. Tidak jarang permasalahan tersebut membuat subjek mengalami penurunan dalam unjuk kerja di sekolahnya, baik nilai, konsentrasi, ataupun malas dalam melakukan aktivitas sekolah.

Pada prosesnya, psikoterapi interpersonal mengacu pada pengurangan gejala depresi yang dialami subjek. Pada kasus subjek dengan orangtua bercerai, permasalahan yang menjadi fokus utama adalah konflik interpersonal yang sering terjadi. Untuk memperbaiki pola komunikasi yang gagal terapis membahas mengenai masalah yang dialami terkait dengan konflik keluarga. Terapis bersama dengan subjek menganalisis komunikasi yang tidak efektif, membantu mencari solusi dengan pemecahan masalah, kemudian subjek diminta role-play bagaimana berkomunikasi secara lebih efektif. Teknik ini sangat sesuai seperti penjelasan dari Robertson, Rushton, dan Wurm (2008) mengenai analisis komunikasi dari psikoterapi interpersonal. Hasil yang diharapkan tentunya berupa pengurangan konflik interpersonal di dalam keluarga yang menjadi faktor munculnya gejala depresi. Pada salah satu subjek yang telah mempraktekkan teknik ini secara langsung dengan orangtua, subjek mendapatkan respon yang positif dari orangtuanya. Orangtua hingga merasa terjadi perubahan positif yang cukup besar pada diri subjek, hingga subjek 
mendapat penghargaan dari orangtuanya. Pada subjek lain, subjek merasa menjadi lebih tahu bagaimana berkomunikasi dengan orang lain sehingga apa yang dimaksudkan tersampaikan dengan baik.

Psikoterapi interpersonal yang berfokus pada pengobatan depresi tentunya memiliki sasaran untuk pengurangan gejala depresi pada setiap indikatornya, salah satunya perubahan suasana hati. Semula subjek merasakan sedih, mudah marah dan tersinggung, putus asa, merasa tidak dianggap di dalam keluarga. Seperti yang dijelaskan oleh Auerbach dan Ho (2012), perasaan sedih, marah, putus asa, dan merasa tidak dianggap merupakan bentuk ketidakmampuan remaja dalam berpikir secara rasional. Subjek tidak mampu mengidentifikasi dan menganalisis akan permasalahan yang terjadi dan apa dampaknya secara psikologis. Dalam hal ini subjek diberikan tahap awal psikoterapi interpersonal yaitu menganalisis gejala yang dirasakan. Subjek diajak untuk memahami bahwa yang dirasakan selama ini merupakan gejala dari depresi dan memotivasi subjek untuk tidak perlu khawatir karena hal itu bisa terjadi oleh siapa saja. Ketika subjek menyadari gejala yang dirasakan dan dialami, subjek dapat lebih mengerti bagaimana mengontrol emosinya dengan baik.

Pada sesi menganalisa tugas kerja konflik yang dialami dan bermain peran terhadap permasalahan yang terjadi dengan melihat komunikasi yang gagal dilakukan selama ini, subjek menjadi menyadari bahwa komunikasi yang tidak efektif merugikan diri sendiri, karena dapat menimbulkan salah persepsi dan pesan yang kita maksud tidak tersampaikan dengan baik. Hal tersebut memunculkan pemahaman baru tentang komunikasi efektif dan mengubah pikiran negatif menjadi lebih positif.

Terkait dengan perubahan reaksi fisiologis seperti sakit kepala, sulit tidur, sulit konsentrasi, nafsu makan terganggu, dan mudah lelah, Goldberg (2013) menjelaskan bahwa kebanyakan orang hanya mengetahui keterkaitan antara emosi dengan gejala depresi, tetapi pada kenyataannya depresi juga berkaitan erat dengan gejala fisik seperti sakit kepala, sakit punggung, tidur yang bermasalah, perubahan berat badan terkait dengan pola makan yang terganggu, dan gangguan nyeri. Pentingnya seseorang mengetahui keterkaitan antara gejala depresi yang menimbulkan reaksi fisik tersebut, agar ia dapat lebih fokus pada penyembuhan psikologis. Dengan berkurangnya gejala depresi seseorang maka akan berkurang juga gejala fisik yang ditimbulkannya. Pada indikator ini subjek diberi penjelasan bahwa hal tersebut merupakan dampak dari gejala depresi dan adanya keterkaitan antara kondisi psikologis seseorang dan reaksi fisiknya. Adanya kemampuan mengendalikan emosi dan konflik ini diharapkan reaksi fisik perlahan akan berkurang seiring berjalannya waktu.

Perubahan pada pola pikir dan sikap diri seperti malas beraktivitas di sekolah, merasa tidak berguna, pemikiran 
masa depan yang negatif, hingga muncul pemikiran untuk bunuh diri yang dirasakan subjek dapat berkurang dengan pemberian teknik perubahan perlaku dengan melihat kelebihan dan kekurangan dalam diri, teknik dan edukasi untuk mengatasi perasaan tertekan, dan pemberian motivasi pada setiap pertemuan. Auerbach dan Ho (2012) menjelaskan secara umum remaja menunjukkan orientasi yang lemah pada masa depan. Hal ini terkait dengan kematangan dan perubahan hormonal yang terjadi. Apabila pada tahap ini subjek mengalami konflik interpersonal seperti menyaksikan perpisahan orangtua dan dampak dari perpisahan, maka secara tidak langsung subjek akan memiliki kekhawatiran dalam menjalin hubungan interpersonal dengan ketika dewasa. Subjek juga menjadi berkurang dalam minat beraktivitas baik di sekolah maupun di luar sekolah, akibatnya subjek sering mengalami penurunan performa di sekolah, sehingga dibutuhkan motivasi dan dorongan untuk mengembalikan semangat berorientasi ke depan.

Pada prosesnya, terapis membangkitkan minat belajar subjek dengan memberikan contoh kisah sukses dari tokoh-tokoh dunia yang mengalami peristiwa serupa dengan subjek atau bahkan lebih menyedihkan, tetapi dapat terus semangat hingga menjadi sukses. Terapis juga memberikan bagaimana teknik dalam mengatasi permasalahan secara positif, dan membantu subjek dalam melakukan perubahan positif dengan melihat kelebihan dan kekurangan dalam diri. Subjek kemudian diminta untuk menuliskan impian atau cita-citanya yang kemudian dibuat poster untuk dipasang di tempat yang selalu dapat terlihat. Hal ini bertujuan untuk mencegah peningkatan gejala depresi atau relaps di kemudian hari. Ketika mengalami peristiwa yang tidak menyenangkan dalam dirinya, subjek diminta untuk melihat mimpinya dan fokus pada tujuan hidupnya. Dengan demikian semangat subjek akan terus terbangun. Hasil yang diperoleh, subjek menjadi lebih semangat lagi dalam mencapai cita-cita yang diinginkan.

Secara akademis, sebagian besar subjek mengalami peningkatan performansi di sekolah, yaitu meningkatnya hasil ujian. Data diperoleh dari hasil wawancara pada waktu follow up. Hal ini dapat disimpulkan bahwa dengan berkurangnya gejala depresi yang dialami oleh subjek, secara tidak langsung akan meningkatkan performa dalam bidang akademis. Seperti yang dijelaskan oleh Rice dan Dolgin (2002) bahwa pada umumnya perceraian orangtua akan membawa dampak yang besar pada anak, baik dari sisi psikologis, kesehatan, maupun akademis. Tujuan khusus dari penelitian ini dapat tercapai, yaitu dengan berkurangnya gejala depresi subjek, maka performa di sekolah dapat meningkat. Hal ini juga terkait dalam sesi motivasi yang diberikan pada setiap pertemuan dengan tujuan meningkatkan kembali semangat dan minat subjek. 
Pada proses mengambil manfaat dalam setiap pertemuan, terdapat beberapa manfaat dari Psikoterapi Interpersonal untuk keenam subjek yang dapat disimpulkan yaitu: (1) Subjek merasa lega karena bisa mengungkapkan perasaan dan emosinya, (2) Subjek menjadi mengerti permasalahan apa yang terjadi pada dirinya dan apa saja dampaknya, (3) Subjek lebih memahami dan menerima kondisi yang telah terjadi, (4) Subjek menjadi lebih sabar dan mampu mengontrol emosi negatif akibat konflik yang dialaminya, (5) Memahami dan dapat mempraktekkan komunikasi efektif, sehingga memperbaiki konflik interpersonal yang secara tidak langsung berkaitan dengan gejala depresi, (6) Subjek mengetahui kekurangan dalam diri dan mengetahui apa yang harus diperbaiki dari dirinya sehingga memudahkan subjek dalam melakukan perubahan perilaku yang lebih positif, (7) Subjek menjadi lebih semangat ke depannya dalam menghadapi kehidupan, dan (8) Subjek tidak lagi mempedulikan pendapat orang lain yang dapat merugikan dirinya.

Keberhasilan psikoterapi interpersonal dalam menurunkan gejala depresi remaja putri dipengaruhi oleh beberapa faktor penting, yakni modul, pelatih (terapis), partisipan, dan fasilitas. Modul dalam psikoterapi interpersonal menggunakan teori yang sudah dimodifikasi untuk remaja, sehingga penggunaan dan sasaran menjadi lebih tepat dan sesuai dengan kebutuhan. Begitu juga dengan terapis yang peneliti tentukan kriteria dengan psikolog klinis perempuan, agar subjek lebih nyaman dalam kegiatan dan terapis memahami gejala klinis yang ada. Partisipan dalam penelitian ini memiliki antusias yang cukup besar, terlihat dari keaktivan masing-masing subjek dalam setiap sesi pada setiap pertemuan. Fasilitas yang diberikan dalam terapi ini berupa pengadaan ruang kelas yang nyaman dengan penggunaan $A C$, pemberian snack setiap pertemuan, dan fasilitas pendukung lainnya seperti map, alat tulis, dan LCD untuk memudahkan penyampaian materi lebih menarik. Berdasarkan penjelasan di atas peneliti menyimpulkan keberhasilan Psikoterapi Interpersonal yaitu (1) modul yang sesuai dengan kebutuhan, (2) terapis yang sesuai dengan kriteria, (3) antusiasme partisipan, dan (4) fasilitas yang memadai.

Penelitian ini memiliki kelemahan, yang pertama peneliti tidak melibatkan orangtua subjek sebagai dalam proses intervensi, sebagai faktor yang dapat memengaruhi kondisi psikologis subjek. Hal ini dikarenakan lokasi orangtua yang tinggal di luar kota, sehingga tidak dimungkinkan untuk ikut terlibat. Kedua tidak ada observasi setelah pelatihan untuk melihat perkembangan subjek. Hal ini dikarenakan sensitivitas yang cukup tinggi pada remaja, sehingga subjek mengganti dengan pemberian diary record. 


\section{SIMPULAN DAN SARAN}

\section{Simpulan}

Simpulan yang diambil berdasarkan hasil analisis yang peneliti lakukan adalah psikoterapi interpersonal memiliki pengaruh dan terbukti efektif untuk menurunkan gejala depresi remaja putri dengan orangtua bercerai. Analisis yang peneliti lakukan kepada masing-masing subjek juga memperoleh hasil yang sangat positif. Setiap subjek merasakan perubahan positif setelah mengikuti psikoterapi interpersonal, baik dari segi emosional maupun perilakunya. Subjek merasa lebih bahagia, dapat berpikir positif, tidak putus asa, memiliki kemampuan komunikasi yang efektif, dan mampu menyelesaikan permasalahan dengan lebih dewasa. Hasil tersebut juga sejalan dengan grafik perubahan masing-masing subjek, di mana subjek mengalami penurunan gejala depresi. Grafik tersebut diperoleh dari hasil tes Beck Depression Inventory (BDIII) yang peneliti lakukan sebelum dan setelah memberi perlakuan. Sebagai refleksi psikoterapi interpersonal lebih efektif pada subjek yang memiliki kepribadian ekstrovert.

\section{Saran}

Saran yang diberikan adalah sebagai berikut. Pertama, saran bagi orangtua yang bercerai. Sebaiknya orangtua dapat lebih peka terhadap gejala depresi yang dialami oleh anak, sekalipun perceraian terjadi pada waktu anak masih kecil. Hal itu dikarenakan berdasarkan hasil pene- litian ini menunjukkan bahwa perceraian yang terjadi ketika anak masih kecil tetap membawa dampak yang cukup besar bagi anak dan dampak tersebut akan terus terbawa hingga anak memasuki usia remaja dan bahkan hingga dewasa.

Kedua, saran bagi pihak sekolah. Sebaiknya kepada Guru Bimbingan Konseling lebih peka terhadap perubahan performa murid di sekolah. Menjalin kerjasama dengan orangtua adalah salah satu langkah yang dapat ditempuh guna menjaga kondisi psikologis anak yang bermasalah. Perlunya komunikasi yang lebih efektif dengan siswa agar dapat lebih terbuka menyampaikan permasalahan yang dialami.

Ketiga, saran bagi sujek penelitian. Sebaiknya dapat mempertahankan kemajuan yang telah diperoleh saat ini. Apabila di kemudian hari mengalami gejala depresi atau emosi negatif, maka diharapkan subjek dapat mempraktekkan teknik dan komunikasi efektif yang telah dipelajari dalam Psikoterapi Interpersonal. Selain itu subjek diharapkan dapat lebih fokus pada impian dan cita-cita ke depannya, sehingga motivasi akan terus terbangun. Bagi salah satu subjek dengan kepribadian introvert disarankan untuk mengikuti terapi individual agar dapat lebih terbuka terhadap permasalahan yang dihadapi.

Keempat, saran bagi peneliti selanjutnya yang ingin meneliti permasalahan serupa terkait dengan konflik remaja dengan orangtua bercerai. Sebaiknya melibatkan orangtua dalam proses intervensi. Hal ini dikarenakan teknik 
komunikasi yang diberikan kepada subjek akan lebih efektif apabila didukung oleh orangtuanya. Bagi peneliti yang ingin melakukan terapi kelompok pada psikoterapi interpersonal, sebaiknya memperhatikan karakteristik kepribadian subjek. Subjek dengan kepribadian introvert disarankan tidak mendapatkan intervensi interpersonal secara kelompok, dikarenakan permasalahan pribadi bagi tipe kepribadian introvert menjadi wilayah personal yang tidak dapat diungkapkan di dalam kelompok. Peneliti selanjutnya juga diharapkan dapat memperhatikan keberhasilan dari intervensi dalam penelitian ini, yaitu modul yang tepat dan terstruktur, terapis sebaiknya memiliki ketrampilan komunikasi yang baik, partisipan dapat terlibat aktif, dan fasilitas yang memadai selama intervensi berlangsung. Bagi peneliti yang ingin melanjutkan penelitian ini diharapkan dapat melihat lebih jauh perubahan subjek setelah mengikuti psikoterapi interpersonal.

\section{DAFTAR PUSTAKA}

Alwisol. (2009). Psikologi Kepribadian (Edisi Revisi). Malang: UMM Press.

Auerbach, R. P., \& Ho. R. (2012). A Cognitive-Interpersonal Model of Adolescent Depression: The Impact of Family Conflict and Depressogenic Cognitive Styles. Journal of Clinical Child \&
Adolescent Psychology. 41, 792802.

Corsini, J. R., \& Wedding, D. (2011). Current Psychotherapies. Edisi 9. Cenange Learning.

Goldberg, J. (2013). Depression: Recognizing the Physical Symptoms. http://www.webmd. com/depression/physical-symptoms.

Grogan, G. L. (2008). The Relation between Attachment to Opposite Sex Parents and Attachment to Romantic Partners. http://scholarworks. boisestate.edu/ cgi/view content.cgi?article $=1019 \&$ context = mcnair journal.

Hurlock, E. B. (2010). Perkembangan Anak. Jilid 1 Edisi 6. Jakarta: Penerbit Erlangga.

Klomek, B. A., Zalsman, G., \& Mufson, L. (2007). Interpersonal Psychotherapy for Depressed Adolescent. Psychiatric Relat Sci. 44.(1), 40-46.

McLean, S. C. (2003). Factors which Could Influence the Development of Adolescent Depression. Thesis. University of South Afrika.

National Institutes of Mental Health (NIMH). (2011). Depression. http://www.nimh.nih.gov/studies/in dex.cfm. 
Oldehinkel, A.J, Ormel, J, Veenstra, R, De Winter, A.F, and Verhulst, F.C. (2008). Parental Divorce and Offspring Depressive Symptoms: Dutch Developmental Trends During Early Adolescence. Journal of Marriage and Family Netherlands. 70, 284-293.

Pengadilan Agama. (2013) Jumlah Perkara Perceraian Di Kota Semarang, http://www.pa-

semarang.go.id/layananpublik/statistik-perkara.html.

Rice, F. P. \& Dolgin, K. G. 2002. The Adolescent: Development, Relationship and The Culture, 10th edition. USA: Allyn \& Bacon Company.

Robertson, M., Rushton, P., \& Wurm. C. (2008). Interpersonal Psychotherapy: An overview. Psychotherapy of Australia. 14, 371-389.
Santrock, J. W. (2003). Adolescence (Perkembangan Remaja). Terjemahan. Jakarta: Penerbit Erlangga.

Sarwono, W. S. (2006). Psikologi Remaja. Edisi revisi 8. Jakarta: Raja Grafindo Pustaka.

Storksen, I, Røysamb, E, Moum, T, Tambs, K. (2005). Adolescents with a Childhood Experience of Parental Divorce: a Longitudinal Study of Mental Health and Adjustment. Journal of Adolescence. 28, 725739.

Suara Merdeka. (2012). Paska Bercerai, Anak Sering Dimaknai Sebagai Properti._http://www.suaramerdeka.

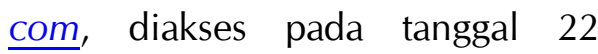
Januari 2012.

Wong, D. L. (2009). Buku Ajar Keperawatan Pediatrik. Vol.1, Edisi 6. Jakarta: Buku Kedokteran EGC. 